\title{
Neutron Activation Analysis of Arsenic, Antimony and Cadmium in Metallic Zinc
}

\author{
Tomihisa Kambara, Junsuke SUZUKI*, Hiroe YoshioKa, \\ and Toshio NAKAMURA** \\ Radiochemistry Research Laboratory, Faculty of Science, Shizuoka \\ University, Shizuoka, *Faculty of Education, Shizuoka University, \\ Shizuoka, ${ }^{* *}$ Faculty of Science, Shinshū University, Matsumoto
}

Received December 13, 1973

\begin{abstract}
Studies were made to establish a rapid and simple radiochemical procedure for the determination of antimony, arsenic and cadmium in metallic zinc by neutron activation analysis. The procedure involves short time irradiation, rapid dissolution of the target and one-step separation of each nuclide $\left({ }^{122} \mathrm{Sb},{ }^{76} \mathrm{As}\right.$ and $\left.{ }^{111 m} \mathrm{Cd}\right)$ from the target nuclides $\left({ }^{65} \mathrm{Zn}\right.$ and $\left.{ }^{69 m} \mathrm{Zn}\right)$.

The irradiated target was rapidly dissolved with hydrochloric acid in the presence of potassium bromate. ${ }^{122} \mathrm{Sb}$ was separated by DEHPA extraction from concentrated hydrochloric acid and ${ }^{78} \mathrm{As}$ by $\mathrm{As}_{2} \mathrm{~S}_{3}$ precipitation in a $6 \mathrm{M}$ hydrochloric acid solution. ${ }^{111 m} \mathrm{Cd}$ was freed from zinc activities by ethyl ether extraction of zinc thiocyanate complex. About half an hour was enough to separate each nuclide from the target. The limits of detection are ca. 30 ppb for antimony, ca. $15 p p b$ for arsenic and ca. 120 ppb for cadmium by short time irradiation of small amounts of the zinc sample.
\end{abstract}

\section{Introduction}

Trace analysis of antimony, arsenic and cadmium in metallic zinc is very important for the study on electrolytic refining of zinc. The radionuclide characters of the three elements ${ }^{1)}$ show that the non-destructive neutron activation analysis is not suitable for the determination of individual element, i.e., the Compton continuum of zinc matrix causes much difficulties in the determination of ${ }^{111 m} \mathrm{Cd}$, and also, very close photo-peaks $\left({ }^{76} \mathrm{As}\right.$ and $\left.{ }^{122} \mathrm{Sb}\right)$ can not be completely resolved from each other. Therefore, it is apparent that these elements should be chemically separated before counting.

The mutual separation of antimony and arsenic has been investigated by ion exchange $\operatorname{method}^{2)}$, distillation method ${ }^{3)}$, precipitation method ${ }^{4,5)}$, and solvent extraction method $^{(8)}{ }^{(8)}$. The solvent extraction and precipitation methods are considered to be a more rapid and simple separation procedure than the other methods. The use of amine extractants such as tri-benzylamine (TBA) was proposed for the rapid and simple separation of antimony and arsenic, but it could not be achieved in concentrated hydrochloric acid solutions ${ }^{8}$. Recently, di-2ethylhexylphosphoric acid (DEHPA) has widely been used as an extractant and some comprehensive investigations have been made on extraction of a number of elements from mineral acid at the concentrations above $1 M^{91}$.

From rapidity, simplicity and completeness of separation, it is considered to be advantageous if each antimony, arseni cand cadmium can be freed from the zinc matrix by one-step separation based on the solvent extraction or the precipitation method. In this paper, we describe a rapid and simple radiochemical procedure for each determination of the elements in metallic zinc together with the results of the determinations.

\section{Experimental}

Reagents: All chemicals used were of 
reagent grade. Di-2-ethylhexylphosphoric acid* (DEHPA) dissolved in equal volume of $n$-heptane was used as the extracting agent. The activation standards of ${ }^{122} \mathrm{Sb}$, ${ }^{76} \mathrm{As}$ and ${ }^{111 \mathrm{~m}} \mathrm{Cd}$ were prepared by neutron irradiation of reagent grade $\mathrm{Sb}_{2} \mathrm{O}_{3}, \mathrm{As}_{2} \mathrm{O}_{3}$ and $\mathrm{CdO}$, respectively.

Neutron irradiation: Appropriate amounts of the samples and the standards were packed with paraffin papers separately, and each of them was sealed in a polyethylene bag. After being packed in a polyethylene rabbit, they were irradiated for $10 \sim 15 \mathrm{~min}$ at a neutron flux of $2.75 \times 10^{13} n / \mathrm{cm}^{2} \cdot \mathrm{sec}$ in the pneumatic tube facilities (Pn-2) of Kyoto University Reactor (KUR).

Apparatus: Measurements of gamma-ray spectra were carried out with a $30 \mathrm{cc} \mathrm{Ge}(\mathrm{Li})$ detector connected to a Nuclear Data 512channel pulse height analyzer. The area under the photo-peak was calculated by a computer, OKITAC 5090, using the KUR program ${ }^{10)}$ including the area determination by the Covell method ${ }^{11}$.

Separation procedure for cadmium: The zinc sample (approximately $25 \mathrm{mg}$ ) irradiated was dissolved with $2 \mathrm{~m} l$ of conc $\mathrm{HCl}$ to which $100 \mathrm{mg} \mathrm{KBrO}_{3}$ and $1 \mathrm{mg} \mathrm{CdO}$ carrier had been added. To the solution was added $8 \mathrm{~m} l$ of distilled water, $10 \mathrm{~m} l$ of $4 M \mathrm{NH}_{4} \mathrm{SCN}$ and $20 \mathrm{~m} l$ of ethyl ether, and the mixture was vigorously shaken for $3 \mathrm{~min}$ to extract the zinc thiocyanate complex ${ }^{12)}$. After the phase separation, $10 \mathrm{~m} l$ of the aqueous phase was transferred to a $50 \mathrm{~m} l$ Erlenmeyer flask, to which $10 \mathrm{ml}$ of ethyl ether was added. The ethyl ether extraction of the thiocyanate complex was repeated. $5 \mathrm{~m} l$ of the aqueous phase was transferred to a polyethylene tube and counted. From the gamma-ray spectra obtained each area under 151 and 245 $\mathrm{keV}$ photo-peaks of ${ }^{111 \mathrm{~m}} \mathrm{Cd}$ was determined. The amounts of cadmium were calculated by using the comparative method, i.e., the area under the $151 \mathrm{keV}$ or $245 \mathrm{keV}$ photopeak for the sample was compared with the corresponding area of the standard with the correction for ${ }^{111 m} \mathrm{Cd}$ decay being made ${ }^{13)}$.

Separation of antimony: The irradiated zinc sample (ca. $50 \mathrm{mg}$ ) was dissolved with $10 \mathrm{~m} l$ of conc $\mathrm{HCl}$ containing $100 \mathrm{mg} \mathrm{KBrO}_{3}$

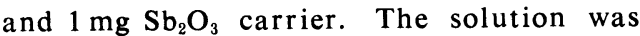
vigorously shaken with $10 \mathrm{~m} l$ of DEHPA solution $(1: 1)$ in $n$-heptane for $3 \mathrm{~min}$ to extract antimony. $5 \mathrm{~m} l$ of the organic phase was counted. From the gamma-ray spectrum obtained, the area under the $564 \mathrm{keV}$ photopeak of ${ }^{122} \mathrm{Sb}$ was computed.

Separation of arsenic: The irradiated zinc sample (ca. $50 \mathrm{mg}$ ) was dissolved with $10 \mathrm{ml}$ of $6 \mathrm{M} \mathrm{HCl}$ containing $100 \mathrm{mg} \mathrm{KBrO}_{3}$ and $5 \mathrm{mg} \mathrm{As} \mathrm{O}_{2} \mathrm{O}_{3}$ carrier. After $1 \mathrm{~g} \mathrm{NH}_{2} \mathrm{OH}$. $\mathrm{HCl}$ was added to the solution for the reduction of $\mathrm{As}(\mathrm{V})$ to $\mathrm{As}(\mathrm{II}), 1 \mathrm{ml}$ of $2 \%$ thioacetamide was added and heated to precipitate arsenic as sulfide. The precipitate was filtered, washed with a $3 M \mathrm{HCl}$ solution and then dissolved in $10 \mathrm{~m} l$ of an ammonium sulfide solution. The gamma-ray spectrum of the solution was measured. The area under the $559 \mathrm{keV}$ photo-peak of ${ }^{76} \mathrm{As}$ was computed.

Preparation of the standards: The irradiated standards $\left(1 \sim 2 \mathrm{mg} \mathrm{As}_{2} \mathrm{O}_{3}, \mathrm{Sb}_{2} \mathrm{O}_{3}\right)$ were dissolved with about $6 \mathrm{M} \mathrm{HCl}$ in a $1,000 \mathrm{~m} l$ volumetric flask to which $50 \mathrm{mg} \mathrm{KBrO}_{3}$ had been added. The standard of $\mathrm{CdO}(1 \sim 2 \mathrm{mg})$ irradiated was dissolved in $10 \mathrm{~m} l$ of $6 \mathrm{M} \mathrm{HCl}$ in a $250 \mathrm{~m} l$ volumetric flask and diluted to the mark with distilled water. Appropriate amounts of these solutions were transferred to polyethylene tubes and counted. The gamma-ray spectra of the separated fractions and the standards were measured under identical conditions.

Tracer experiment: The analytical procedures proposed as mentioned above were tested by using $25 \sim 50 \mathrm{mg}$ zinc (almost equal amounts used in the practical analysis) and the tracers of ${ }^{65} \mathrm{Zn},{ }^{115} \mathrm{Cd},{ }^{124} \mathrm{Sb}$ and ${ }^{74} \mathrm{As}$.

\section{Results and Discussion}

It was found by the tracer studies that the zinc sample could be rapidly dissolved with negligible loss of ${ }^{124} \mathrm{Sb}$ or ${ }^{74} \mathrm{As}$. The

* Obtained from Tokyo Kasei Co., Ltd.; it contained MEHPA (15\%) and other alkyl phosphate $(5 \%)$. 
$\mathrm{HCl}+\mathrm{KBrO}_{3}$ dissolution method is found to be a better method than the ordinary aqua regia dissolution method ${ }^{14)}$.

As to the isolation of cadmium activity from the zinc matrix the ethyl ether extraction yield of zinc was found to be more than $99 \%$ at $1.2 \mathrm{M} \mathrm{HCl}$ and $2 \mathrm{M} \mathrm{NH}_{4} \mathrm{SCN}$, whereas that of cadmium was less than $0.1 \%$, i.e., no correction for the chemical yield was needed.

The results of DEHPA extraction of antimony and arsenic are shown in Fig. 1. The results show no extraction of arsenic from concentrated hydrochloric acid solutions into DEHPA containing some other alkylphosphoric acid, indicating that the use of such DEHPA gives far better results than that of pure DEHPA for separation of antimony from arsenic according to the synergistic effect. As to the separation of arsenic from antimony arsenic can be quantitatively precipitated from $6 \mathrm{M} \mathrm{HCl}$, whereas antimony showed little coprecipitations.

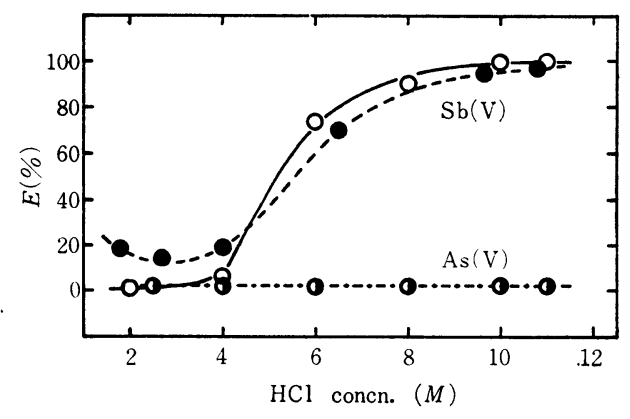

Fig. 1 Effect of $\mathrm{HCl}$ concentration on the extraction of $\mathrm{Sb}(\nabla)$ and $\mathrm{As}(\nabla)$ ions in to DEHPA (obtained from Tokyo Kasei Co., Ltd., not pure).

The dotted line shows the results of the extraction of $\mathrm{Sb}(\nabla)$ with pure DEHPA according to Levin, et al. ${ }^{15)}$

From the results of the tracer experiments as mentioned above, it was found that the determinations of cadmium, antimony and arsenic in metallic zinc could be performed by one-step separation procedure of each element based on extraction or precipitation.
The gamma-ray spectra of the fractions isolated from the activated zinc target showed clearly that the mutual separation of antimony, arsenic and cadmium can be achieved by application of the scheme. The results are shown in Table 1 . These values were in good agreement with those obtained by the colorimetric method with brilliant green $^{16)}$ for antimony, by the standard addition method ${ }^{17)}$ in neutron activation analysis for arsenic and by the polarographic method $^{18)}$ for cadmium.

Table 1 Determinations of antimony, arsenic and cadmium in zinc*

\begin{tabular}{c|c|c|c}
\hline Element & $\begin{array}{c}\text { Sp. grade } \\
(\mathrm{ppm})\end{array}$ & $\begin{array}{c}\text { 1st grade } \\
(\mathrm{ppm})\end{array}$ & $\begin{array}{c}\text { Sample** } \\
(\mathrm{ppm})\end{array}$ \\
\hline Antimony & $1.03 \pm 0.18$ & $19.2 \pm 1.9$ & $2896 \pm 110$ \\
& - & $19.5 \pm 1.1^{\mathrm{a})}$ & - \\
Arsenic & $0.37 \pm 0.10$ & $1.09 \pm 0.27$ & $51.4 \pm 7.6$ \\
& - & - & $48.5 \pm 6.1^{\mathrm{b} \gamma}$ \\
Cadmium & $340 \pm 34$ & $5090 \pm 940$ & $1046 \pm 15$ \\
& $341 \pm 25^{\mathrm{c})}$ & $\left.5110 \pm 314^{\mathrm{c}}\right)$ & $1074 \pm 82^{\mathrm{c}}$ \\
\hline
\end{tabular}

The value is the average of at least five determinations and the error is the standard deviation of them.

* K. Chemical Co., Ltd.

** Obtained from Zinc Manufacture Co.

a) Colorimetric method with brilliant green; b) Standard addition method in neutron activation analysis; c) Polarographic method

The time for carrying out the separation scheme proposed for each determination of antimony, arsenic and cadmium is about $40 \mathrm{~min}$, including irradiation of the sample. Dissolution of the target and chemical separation for element are simple, rapid and quantitative. The limits of detection are estimated to be ca. $30 \mathrm{ppb}$ for antimony, 15 ppb for arsenic and $120 \mathrm{ppb}$ for cadmium by neutron irradiation ( $10 \mathrm{~min}$ for cadmium, 15 min for antimony and arsenic) with the counting time of $400 \mathrm{sec}$.

\section{Acknowledgment}

The most parts of this work were done under the Visiting Researchers Program of Kyoto University Research Reactor Institute. We would like to express our hearty thanks 
to Dr.C. Tamai who helped us for the data processing with the use of KUR program.

\section{References}

1) F. Adams and R. Dams: J. Radioanal. Chem., 3, 99 (1969)

2) R. Kuroda, K. Ishida and T. Kiriyama: Anal. Chem., 40, 1502 (1968)

3) A. Mizuike and T. Kono: Radioisotopes, 19, 609 (1970)

4) N. Maenhaut, F. Adams and J. Hoste: J. Radioanal. Chem., 6, 83 (1970)

5) E. Steinnes: Analyst, 97, 241 (1972)

6) A. Alian, R. Shabana, W. Sanad, B. Alian and K. Khalifa: Talanta, 15, 262 (1968)

7) J. Ruzika, J. Stary and A. Zeman: ibid., 11, 1151 (1964)

8) I.H. Qureshi, F.I. Nagi, M. Nasra and M.N. Cheema： J. Radioanal. Chem., 7, 221 (1971)

9) I.H. Qureshi, L.T. McClendon and P.D. Lafleur: Proceedings, "International Conference on Modern Trends in Ac- tivation Analysis," 666, NBS, Washington, D.C. (1968)

10) Y. Kiso and C. Tamai: Genshiryoku Kogyo, 17, 38 (1971)

11) D.F. Covell: Anal. Chem., 31, 1785 (1959)

12) G.H. Morrison and H. Freiser: "Solvent Extraction in Analytical Chemistry", 136, John Wiley and Sons, Inc., New York (1957)

13) P.T. Wagner: Nucleonics, 13, 54 (1955)

14) B.A. Thompson and P.D. LaFleur: Anal. Chem., 41, 852 (1969)

15) I.S. Levin, A.A. Shatalova, F.C. Azarenko, I.A. Vorsina, N.A. BurtovayaBalakireva and T.F. Rodina: Talanta, 14, 801 (1967)

16) R.E. Stanton and A.J. McDonald: Analyst, 87, 299 (1962)

17) G. Leliaert, J. Hoste and Z. Eekhaut: Anal. Chim. Acta, 19, 100 (1958)

18) I.M. Kolthoff and J.J. Lingane: "Polarography," Second ed., 503, Interscience Publishers, New York, London (1952)

\title{
要 旨
}

\author{
金属覀鉛中のヒ素，アンチモン，カドミウムの中性子放射化分析 \\ 神原富尚，鈴木諒亮*，吉岡濶江，中村俊夫** \\ 静岡大学理学部付属放射化学研究施設, \\ $*$ 静岡大学教育学部, $* *$ 信州大学理学部
}

\footnotetext{
金属要鉛中のヒ素，アンチモン，カドミウムについて，迅速かつ簡便な定量法として中性子放射 化分析法を検討した。すなわち，試料の短時間照射，迅速溶解法，ターゲットから目的元素の迅速 分離法などが検討された。

ターゲットの溶解は臭素酸カリウムの塩酸浴液を用い,ターダットよりアンチモンの分離は濃塩

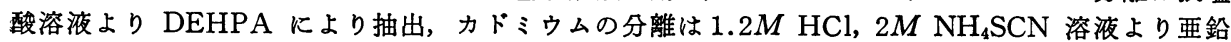
をロダン錯体としてエーテルに抽出，ヒ素は $6 M \mathrm{HCl}$ 溶液より硫化ヒ素として沈殿分離させた。 これら分離に要する時間は約30分ときわめて迅速であり，また，アンチモン，七素の同時定量も可 能であることがわかった。
} 